\title{
Karakteristik keluarga yang berhubungan dengan status gizi balita umur 6- 59 bulan
}

\author{
Rachma Purwanti ${ }^{1}$, Erna Kusuma Wati ${ }^{1}$, Setiyowati Rahardjo ${ }^{1}$
}

\begin{abstract}
Background: Nutrition is a factor that most determines the quality of human resources. Lack of nutrition during infancy can lead delayed in physical growth, motor development and impaired cognitive development. Family characteristics holds an important role to solve nutrition problems.

Objective: to determine the family characteristics associated with nutritional status of children at the Community Health Centers of Sumbang II, Banyumas Regency.

Methods: This type of study is a case - control. Sample cases were children aged 6-59 months who have undernutrition status, while the controls were well nourished children aged 6-59 months. Sample of cases and controls each of 46. Data was analyzed using univariate, bivariate, and multivariate methods.

Result: Based on this research, it is known that the characteristics of the families studied, which are associated with nutritional status of children in the Community Health Center II Sumbang, Banyumas Regency is the level of mother's nutritional knowledge with a p value $=0.002$ and $O R=3.875$. Other variable of family characteristics, namely large families, health care utilization, and environmental sanitation were not associated with nutritional status of children ( $p=0.921$; $p=0.173 ; p=0.204)$.

Conclusion: Level of mother's nutritional knowledge was associated with nutritional status. As a suggestion, to improve nutritional status on children at the Community Health Centers of Sumbang II it need to increase knowledge of mothers by training and counseling, better supervision and monitoring of nutritional status of children, and increase roles of an integrated services post.
\end{abstract}

Key word: Family characteristics, children nutritional status

\section{ABSTRAK}

Latar Belakang: Gizi merupakan faktor yang mempengaruhi kualitas sumber daya manusia. Kekurangan zat gizi selama masa pertumbuhan dapat berdampak pada keterlambatan pertumbuhan fisik, perkembangan motorik dan kognitif. Karakteristik keluarga memegang peranan penting dalam mengatasi permasalahan gizi.

Tujuan: Menganalisis hubungan antara karakteristik keluarga dengan status gizi balita di wilayah Puskesmas II Sumbang, Kabupaten Banyumas. Metode: Penelitian ini menggunakan desain kasus - kontrol. Sampel kasus merupakan balita yang berumur 6 - 59 bulan dan mempunyai status gizi kurang / buruk, sedangkan sampel kontrol merupakan balita berstatus gizi baik berumur 6 - 59 bulan. Masing-masing sampel (kelompok kasus dan kontrol) sebanyak 46 balita. Data dianalisis secara univariat, bivariat, dan multivariat.

Hasil Penelitian: Berdasarkan hasil penelitian diketahui bahwa diantara variabel karakteristik keluarga yang diteliti, variabel yang berhubungan dengan status gizi balita adalah pengetahuan gizi ibu $(p=0,002$ dan OR = 3,875). Adapun besar keluarga, pemanfaatan pelayanan kesehatan, dan sanitasi lingkungan tidak berhubungan dengan status gizi balita $(p=$ 0,921; $p=0,173$; dan $p=0,204$ ).

Simpulan dan Saran: Pengetahuan berhubungan dengan status gizi balita. Upaya mengatasi masalah gizi buruk pada balita di Puskesmas II Sumbang dapat dilakukan melalui penyuluhan dan pelatihan gizi, supervisi dan pemantauan status gizi balita secara aktif, serta optimalisasi pelayanan 5 meja di posyandu.

Kata kunci: karakteristik keluarga, status gizi balita

\section{PENDAHULUAN}

Faktor gizi merupakan faktor yang paling menentukan kualitas Sumber Daya Manusia (SDM). ${ }^{1}$ Kekurangan gizi pada masa pertumbuhan dapat menyebabkan keterlambatan pertumbuhan fisik, perkembangan motorik, dan gangguan perkembangan kognitif. $^{2}$

\footnotetext{
1. Jurusan Kesehatan Masyarakat, Fakultas Kedokteran dan Ilmu-ilmu Kesehatan, Universitas Jenderal Soedirman (email korespondensi: purwantirachma@gmail.com)
}

Gizi kurang yaitu keadaan kekurangan zat gizi pada anak balita (usia 0 - 59 bulan) yang disebabkan oleh rendahnya asupan energi dan protein dalam waktu cukup lama dan ditandai dengan berat badan menurut umur $(\mathrm{BB} / \mathrm{U})$ yang berada antara -3 SD sampai -2 SD tabel baku WHO-NCHS (Pusat Data dan Informasi, 2006). ${ }^{1}$ Gizi kurang disebabkan oleh beberapa faktor yaitu penyebab langsung, tidak langsung, dan akar masalah. Karakteristik keluarga (kemiskinan, kesehatan lingkungan, aksesibilitas pangan pada tingkat keluarga, penyakit infeksi, pola asuh ibu, dan akses keluarga terhadap pelayanan kesehatan dasar) 
akan mempengaruhi pengetahuan, sikap, dan perilaku gizi ibu dalam penanganan masalah gizi. ${ }^{3}$

Berdasarkan hasil penelitian sebelumnya, diketahui bahwa besar keluarga berhubungan dengan lama waktu asuh balita yang berhubungan dengan konsumsi makan balita status gizi kurang dan gizi buruk. ${ }^{4}$ Penelitian lain menunjukkan bahwa ada hubungan antara pendidikan ibu, jumlah paritas, dan tingkat pengetahuan gizi dengan status gizi balita. ${ }^{5}$ Adapun sanitasi lingkungan berhubungan dengan penyakit infeksi diare pada balita. Infeksi merupakan penyebab langsung yang berhubungan dengan status gizi. $^{6}$

Berdasarkan hasil Riset Kesehatan Dasar (Riskesdas) Tahun 2010, diketahui prevalensi balita gizi kurang secara nasional sebesar 13\% dan gizi buruk 4,9\%. ${ }^{7}$ Prevalensi gizi kurang di Propinsi Jawa Tengah berdasarkan hasil Riskesdas Tahun 2010 sebesar $12,4 \%$, sedangkan prevalensi gizi buruk sebesar 3,3\%. Prevalensi tersebut perlu diwaspadai karena terdapat kecenderungan meningkat. ${ }^{7,8}$

Berdasarkan Profil Kesehatan Propinsi Jawa Tengah Tahun 2011, diketahui bahwa Kabupaten Banyumas menempati urutan ke-5 tertinggi di Jawa Tengah untuk kasus gizi buruk balita. ${ }^{9}$ Berdasarkan Profil Dinas Kesehatan Kabupaten Banyumas Tahun 2011, diketahui bahwa jumlah balita yang menderita gizi buruk sebesar $0,16 \%$, lebih tinggi daripada tahun sebelumnya sebesar $0,05 \% .^{10}$

Sumbang merupakan salah satu wilayah di Kabupaten Banyumas yang menghadapi permasalahan kesehatan dan gizi masyarakat. Profil kesehatan Kabupaten Banyumas Tahun 2011 menunjukkan bahwa jumlah Balita Bawah Garis Merah (BGM) di wilayah Puskesmas II Sumbang menempati peringkat ke-3 tertinggi di Kabupaten Banyumas. ${ }^{10}$ Berdasarkan Profil Puskesmas II Sumbang (2011), diketahui bahwa persentase BGM sebesar 5,01\% dan gizi buruk 0,28\%, lebih tinggi dibanding persentase BGM Kabupaten Banyumas yaitu $1,95 \%$ dan gizi buruk $0,16 \%$, sehingga perlu diwaspadai. ${ }^{11}$

Penelitian-penelitian terkait status gizi menunjukkan bahwa status gizi juga dipengaruhi tiga faktor utama yaitu pola asuh, ketersediaan dan pola konsumsi rumah tangga, pelayanan kesehatan, dan kesehatan lingkungan. Ketiga faktor tersebut beroperasi di tingkat keluarga. ${ }^{12}$ Karakteristik keluarga merupakan penyebab tidak langsung status gizi yang sampai saat ini belum banyak diteliti. Oleh karena itu, penulis tertarik untuk meneliti "Karakteristik keluarga yang berhubungan dengan status gizi balita di wilayah Puskesmas II Sumbang Kabupaten Banyumas”.

\section{BAHAN DAN METODE}

Penelitian ini menggunakan desain studi observasional analitik kasus kontrol retrospektif. Lokasi penelitian adalah wilayah Puskesmas II Sumbang Kabupaten Banyumas. Populasi kasus berjumlah 75 anak dan populasi kontrol berjumlah 3381 anak.

Berdasarkan hasil perhitungan besar sampel studi kasus-kontrol menurut Lemeshow et al., ${ }^{13}$ didapatkan sampel sebesar 46 untuk kelompok kasus dan 46 untuk kelompok kontrol. Responden adalah ibu dari balita dari kelompok kasus dan kontrol.

Teknik pengambilan sampel untuk sampel kasus adalah purposive sampling. Sampel kontrol diambil dari tetangga terdekat kasus yang memiliki status gizi baik. Instrumen yang digunakan dalam penelitian ini adalah kuesioner, checklist, dan timbangan injak. Sebelum dilakukan penelitian, peneliti melakukan uji validitas dan reliabilitas kuesioner. Analisis yang dilakukan meliputi analisis univariat dengan distribusi frekuensi, bivariat dengan chi square, dan multivariat dengan regresi logistik ganda.

\section{HASIL}

\section{Karakteristik Responden}

Sebagian besar responden berumur antara 20 35 tahun (68.5\%). Pendidikan terakhir sebagian besar responden $(63 \%)$ adalah tamat SD. Sebagian besar responden (75\%) tidak bekerja (Ibu Rumah Tangga).

Rata-rata pendapatan sebesar Rp. 1.001.684,00/bulan. Rata-rata pendapatan per kapita (setelah dibagi jumlah anggota keluarga) adalah Rp. 213.911,63/bulan. Pendapatan per kapita 100\% berada di bawah UMR Kabupaten Banyumas $(<\mathrm{Rp}$. $795.000,00)$.

\section{Karakteristik Balita}

Sebanyak 35,9\% balita berumur 25 - 36 bulan. Lebih dari separuh persentase balita berjenis kelamin perempuan $(57,6 \%)$.

\section{Analisis Univariat}

Hasil analisis univariat menunjukkan bahwa lebih dari separuh jumlah responden $(58,7 \%)$ memiliki anggota keluarga berjumlah $\geq 4$ orang (keluarga besar), lebih dari separuh jumlah responden $(51,1 \%)$ memiliki pengetahuan baik. Sebagian besar responden $(71,7 \%)$ memanfaatkan pelayanan kesehatan dengan baik. Responden yang memiliki sanitasi baik dan kurang baik masing-masing sebesar 50\%. Sebesar $72,8 \%$ balita pernah mengalami infeksi dalam 1 bulan terakhir dengan jenis penyakit infeksi yang paling banyak yaitu ISPA $(48,9 \%)$. 
Jenis bahan makanan yang paling banyak dikonsumsi pada tiap kelompok pangan hampir sama pada kelompok kasus dan kontrol. Namun, perbedaan konsumsi makanan terlihat pada frekuensi konsumsi umbi, minyak goreng, gula, buah-buahan (pisang dan jeruk), kacang hijau, dan teh.

\section{Analisis Bivariat}

Tabel 1. menunjukkan bahwa proporsi balita yang tinggal dalam keluarga besar ( $\mathrm{n}>4$ orang) pada kelompok kasus (63\%) lebih besar dibandingkan kelompok kontrol $(54,3 \%)$. Tidak ada hubungan antara besar keluarga dengan status balita $(\mathrm{p}=0,525)$. Proporsi balita yang pengetahuan gizi ibunya kurang pada kelompok kasus $(65,2 \%)$, lebih besar daripada kelompok kontrol $(32,6 \%)$. Ada hubungan antara pengetahuan gizi ibu dengan status balita $(\mathrm{p}=0,004$; $\mathrm{OR}=3,875 ; 95 \% \mathrm{CI}=1,632-9,203)$. Proporsi balita yang kurang memanfaatkan pelayanan kesehatan pada kelompok kasus $(37,0 \%)$, lebih besar daripada kelompok kontrol $(23,9 \%)$. Tidak ada hubungan antara pemanfaatan pelayanan kesehatan dengan status balita $(\mathrm{p}=0,257)$. Proporsi balita yang tinggal di lingkungan dengan sanitasi kurang baik pada kelompok kasus $(58,7 \%)$, lebih besar dibandingkan kelompok kontrol $(41,3 \%)$. Hasil analisis bivariat menunjukkan tidak ada hubungan bermakna antara sanitasi lingkungan dengan status balita $(\mathrm{p}=0.144)$.

Tabel 1. Hubungan antara Karakteristik Keluarga dengan Status Gizi Balita di Wilayah Puskesmas II Sumbang Kabupaten Banyumas

\begin{tabular}{|c|c|c|c|c|c|c|c|}
\hline \multirow{3}{*}{ No. } & \multirow{3}{*}{$\begin{array}{l}\text { Karakteristik } \\
\text { Keluarga }\end{array}$} & \multicolumn{4}{|c|}{ Status balita } & \multirow{3}{*}{$\mathbf{p}$} & \multirow{3}{*}{ OR } \\
\hline & & \multicolumn{2}{|c|}{ Kasus } & \multicolumn{2}{|c|}{ Kontrol } & & \\
\hline & & $\mathbf{n}$ & $\%$ & $\mathbf{n}$ & $\%$ & & \\
\hline \multirow[t]{3}{*}{1.} & Besar Keluarga & & & & & & \\
\hline & Besar & 29 & 63 & 25 & 54,3 & 0,525 & 1,433 \\
\hline & Kecil & 17 & 37 & 21 & 45,7 & & \\
\hline \multirow[t]{3}{*}{2.} & Pengetahuan & & & & & & \\
\hline & Kurang & 30 & 65,2 & 15 & 32,6 & 0,004 & 3,875 \\
\hline & Baik & 16 & 34,8 & 31 & 67,4 & & \\
\hline \multirow[t]{3}{*}{3.} & Pemanfaatan Yankes & & & & & & \\
\hline & Kurang & 17 & 37,0 & 11 & 23,9 & 0,257 & 1,865 \\
\hline & Baik & 29 & 63,0 & 35 & 76,1 & & \\
\hline \multirow[t]{3}{*}{4.} & Sanitasi Lingkungan & & & & & & \\
\hline & Kurang & 27 & 58,7 & 19 & 41,3 & 0,144 & 2,019 \\
\hline & Baik & 19 & 41,3 & 27 & 58,7 & & \\
\hline
\end{tabular}

\section{Analisis Multivariat}

Tabel 2. menunjukkan bahwa karakteristik keluarga yang berhubungan secara bersama-sama dengan status gizi balita di wilayah Puskesmas II Sumbang adalah pengetahuan gizi ibu dengan nilai $\mathrm{p}=$
0,002 dan OR=3,875. Balita dengan ibu yang pengetahuan gizinya kurang mempunyai risiko 3,875 kali lebih besar untuk memiliki status gizi kurang atau buruk dibandingkan balita dengan ibu yang pengetahuan gizinya baik.

Tabel 2. Model Akhir Hasil Analisis Multivariat

\begin{tabular}{ccccc}
\hline No. & \multicolumn{1}{c}{ Variabel } & B & p & OR \\
\hline 1. & Pengetahuan gizi Ibu & 1,355 & 0,002 & 3,875 \\
\hline 2. & Constant & $-0,661$ & 0,032 & 0,516 \\
\hline
\end{tabular}

\section{PEMBAHASAN}

Berdasarkan hasil penelitian diketahui bahwa karakteristik keluarga yang berhubungan dengan status gizi balita di wilayah Puskesmas II Sumbang adalah pengetahuan gizi ibu, sedangkan besar keluarga, pemanfaatan pelayanan kesehatan, dan sanitasi lingkungan tidak berhubungan.
Karakteristik keluarga yang berhubungan secara bersama-sama dengan status gizi balita : pengetahuan gizi ibu

Berdasarkan analisis multivariat dengan uji regresi logistik ganda diketahui bahwa karakteristik keluarga yang berhubungan secara bersama-sama dengan status gizi balita adalah pengetahuan gizi dengan nilai $\mathrm{p}=0,002$ dan $\mathrm{OR}=3,875$.

Hasil penelitian ini sejalan dengan hasil penelitian sebelumnya yang menyatakan bahwa ada hubungan antara tingkat pengetahuan gizi ibu dengan 
tingkat konsumsi protein yang berdampak pada status gizi balita. ${ }^{14}$ Hasil serupa juga didapatkan pada penelitian terdahulu yang menyatakan bahwa ada hubungan antara tingkat pengetahuan gizi ibu dengan status gizi balita keluarga petani. ${ }^{15}$ Sejalan dengan penelitian lainnya yang menyatakan bahwa intervensi dalam rangka meningkatkan pengetahuan gizi dan kesehatan berhubungan dengan peningkatan anggapan pentingnya pemberian suplemen bagi balita dan peningkatan status gizi balitanya. ${ }^{16}$

Pengetahuan gizi ibu yang kurang pada penelitian ini dilatar belakangi pendidikan ibu yang kurang yaitu sebagian besar hanya tamat SD (63\%). Tingkat pendidikan akan menentukan mudah tidaknya proses adopsi teknologi dan penyerapan pengetahuan. ${ }^{3}$ Oleh karenanya seorang yang berpendidikan lebih tinggi akan memungkinkannya menyerap pengetahuan dan teknologi dengan lebih baik. Pendidikan dan pengetahuan gizi akan berpengaruh terhadap konsumsi makanan pada balita yang pada akhirnya berdampak pula pada status gizi.

\section{Karakteristik keluarga yang tidak berhubungan secara bersama-sama dengan status gizi balita}

\section{Besar keluarga}

Hasil uji multivariat pada penelitian ini menunjukkan bahwa tidak ada hubungan signifikan antara besar keluarga dan status gizi balita $(\mathrm{p}=0,921)$.

Hasil penelitian ini sejalan dengan penelitian terdahulu yang menyatakan bahwa tidak ada hubungan antara jumlah anggota keluarga dengan status gizi balita di Dukuh Madigondo, Desa Sidoharjo, Kecamatan Samigaluh, Kabupaten Kulonprogo. ${ }^{17}$ Hasil penelitian ini tidak sejalan dengan penelitian lain yang melaporkan bahwa ada hubungan antara besar keluarga dengan status gizi balita di Islamabad, Pakistan. ${ }^{18}$ Hasil penelitian juga tidak sejalan dengan penelitian lainnya yang melaporkan adanya hubungan antara besar keluarga dengan pola asuh dan status gizi balita $^{4}$ dan hasil penelitian lain yang menyebutkan adanya hubungan antara besar keluarga dengan malnutrisi pada balita dan kematian akibat malnutrisi. ${ }^{19}$

Tidak adanya hubungan antara besar keluarga dengan status gizi balita pada penelitian ini dikarenakan lebih dari separuh jumlah balita $(58,7 \%)$ tinggal dalam keluarga besar yang beranggotakan lebih dari 4 orang. Selain itu, ada kecenderungan yang hamper sama pada kelompok kasus dan kontrol yaitu tinggal dalam lingkungan keluarga besar $(54,3 \%)$. Sebagian besar $(70,4 \%)$ responden yang tinggal dalam keluarga besar telah memanfaatkan pelayanan kesehatan dengan baik, sehingga menurunkan risiko untuk terjadinya status gizi kurang atau gizi buruk pada balitanya.

\section{Pemanfaatan Pelayanan Kesehatan}

Berdasarkan hasil uji multivariat, diketahui bahwa pemanfaatan pelayanan kesehatan tidak berhubungan dengan status gizi balita $(\mathrm{p}=0,173)$. Tidak adanya hubungan antara pemanfaatan pelayanan kesehatan dengan status gizi balita pada penelitian ini dikarenakan sebagian besar balita $(71,7 \%)$ telah memanfaatkan pelayanan kesehatan dengan baik.

Responden pada kelompok kasus dan kontrol juga memiliki kecenderungan yang hampir sama dalam memanfaatkan pelayanan kesehatan yaitu terkait rutinitas menimbang balita di posyandu sesuai kategori umur, kebiasaan mengunjungi pelayanan kesehatan jika anak sakit dan status gizi balita tidak baik, balita mendapatkan kapsul vitamin A setiap bulan Februari dan Agustus, dan diimunisasi secara lengkap sesuai umur.

Hasil penelitian ini sejalan dengan terdahulu yang melaporkan bahwa tidak ada hubungan antara akses terhadap pelayanan kesehatan dengan status gizi balita di Dukuh Madigondo, Desa Sidoharjo, Kecamatan Samigaluh, Kabupaten Kulonprogo. ${ }^{17}$

\section{Sanitasi lingkungan}

Berdasarkan hasil analisis multivariat diketahui bahwa tidak ada hubungan antara sanitasi lingkungan dengan status gizi balita di wilayah Puskesmas II Sumbang Kabupaten Banyumas $(p=0,204)$. Tidak adanya hubungan antara sanitasi lingkungan dengan status gizi balita dikarenakan responden pada kelompok kasus dan kontrol memiliki kecenderungan hampir sama yaitu keberadaan tempat penampungan air dan tempat sampah, pencahayaan rumah yang cukup, Saluran Pembuangan Air Limbah (SPAL), dan kualitas air. Selain itu, sebesar 73,9\% responden yang sanitasi lingkungan rumahnya kurang baik telah memanfaatkan pelayanan kesehatan dengan baik. Hasil penelitian ini sejalan dengan penelitian sebelumnya yang melaporkan bahwa tidak ada hubungan antara hygiene sanitasi lingkungan dengan status gizi balita. ${ }^{17}$

\section{SIMPULAN}

Sebanyak $58,7 \%$ responden tinggal bersama keluarga besar. Lebih dari separuh jumlah responden $(51,1 \%)$ memiliki pengetahuan baik. Sebagian besar responden $(71,7 \%)$ memanfaatkan pelayanan kesehatan baik. Responden yang mempunyai sanitasi lingkungan baik dan kurang baik masing-masing sebesar $50 \%$. Sebesar 72,8\% balita pernah mengalami sakit infeksi dalam 1 bulan terakhir. Konsumsi makanan pada kelompok kasus dan kontrol memiliki perbedaan yaitu pada frekuensi konsumsi umbi, minyak goreng, gula, buah-buahan (pisang dan jeruk), kacang hijau, dan teh. 
Tidak ada hubungan antara besar keluarga dengan status gizi balita dengan $p=0,921$. Ada hubungan antara pengetahuan gizi ibu dengan status gizi balita dengan $p=0,002$ dan $O R=3,875$. Tidak ada hubungan antara pemanfaatan pelayanan kesehatan dengan status gizi balita dengan $p=0,173$. Tidak ada hubungan antara sanitasi lingkungan dengan status gizi balita dengan $p=0,204$. Karakteristik keluarga yang berhubungan secara bersama-sama dengan status gizi balita balita di wilayah Puskesmas II Sumbang Kabupaten Banyumas adalah pengetahuan gizi ibu.

\section{SARAN}

Diharapkan adanya upaya peningkatan pengetahuan gizi ibu balita melalui penyuluhan dan pelatihan gizi, supervisi dan pemantauan status gizi balita secara aktif, serta pengaktifan fungsi dan peran posyandu dengan optimalisasi pelayanan 5 meja di posyandu.

\section{DAFTAR PUSTAKA}

1. Glosarium Data dan Informasi Kesehatan. Pusat Data dan Informasi. Jakarta: Departemen Kesehatan Republik Indonesia; 2006.

2. Martorell, R. Undernutrition During Pregnancy and Early Childhood and its Consequences for Behavioral Development. Paper prepared for World Bank's conference on Early Child Development: Investing in the Future, 1996 April $8 \& 9$

3. Rencana Aksi Nasional Pangan dan Gizi Tahun 2011-2015. Jakarta: Kementerian Perencanaan Pembangunan Nasional, Badan Perencanaan Pembangunan Nasional, Bappenas; 2011.

4. Suranadi, L. dan Candradewi. Studi tentang Karakteristik Keluarga dan Pola Asuh pada Balita Gizi Kurang dan Gizi Buruk di Kabupaten Lombok Barat. Jurnal Kesehatan Prima. 2008 Agustus; $02(02)$ : p. $296-303$.

5. Andra N, Hestu W, Aditya YA. Hubungan karakteristik ibu terhadap status gizi balita di Kabupaten Kendal. Jurnal Unimus. 2014: p. 1-6.

6. Sutariya, S., N. Talsania, C. Shah. Study of Prevalence of Diarrhoeal Diseases Amongst Under Five Population. National Journal of Community Medicine. 2011; 2 (1): p. 96-99.

7. Laporan Hasil Riset Kesehatan Dasar Tahun 2010. Jakarta: Badan Penelitian dan Pengembangan Kesehatan (BP2K); 2011.
8. Laporan Hasil Riset Kesehatan Dasar Tahun 2007. Jakarta: Badan Penelitian dan Pengembangan Kesehatan (BP2K); 2008.

9. Profil Kesehatan Propinsi Jawa Tengah Tahun 2011. Semarang: Dinas Kesehatan Propinsi Jawa Tengah; 2011.

10. Profil Kesehatan Kabupaten Banyumas Tahun 2010. Purwokerto: Dinas Kesehatan Kabupaten Banyumas; 2011.

11. Profil Puskesmas II Sumbang Tahun 2011.

12. Shrimpton, R. Life Cycle and Gender Perspectives on the Double Burden of Malnutrition and the Prevention of Diet Related Chronic Diseases. Standing Commite on Nutrition. 2006; (33).

13. Lemeshow S., D.W. Hosmer Jr, J. Klar, S.K. Lwanga. Adequacy of Sample Size in Health Studies. WHO. John Wiley \& Sons; 1990.

14. A. Ernawati. Hubungan Faktor Sosial Ekonomi, Higiene Sanitasi Lingkungan, Tingkat Konsumsi, dan Kejadian Infeksi dengan Status Gizi Anak Usia 2-5 Tahun di Kabupaten Semarang. Tesis. Magister Gizi Masyarakat. Program Pascasarjana. Universitas Diponegoro, Semarang. 2006; 1-99.

15. D. Andarwati. Faktor-faktor yang berhubungan dengan status gizi balita pada keluarga petani di Desa Purwojati Kecamatan Kertek Kabupaten Wonosobo. Skripsi. Jurusan Ilmu Kesehatan Masyarakat. Fakultas Ilmu Keolahragaan. Universitas Negeri Semarang. 2007; 1-138.

16. Bonvecchio. A., Gretel H.P., Erika E., Erick M., Habicht, Fernanda N., Maria A. V., Margarita S., dan J. A. Rivera. Maternal Knowledge and Use of a Micronutrient Supplement Was Improved with a Programmatically Feasible Intervention in Mexico. The Journal of Nutrition. 2007; (137): p. 440 - 446.

17. W. H. Istiono, Suryadi, M. Haris, Irni Z., Andre D.T., M. A. Hasdianda, Tika F., T.I.R. Sidabutar. Analisis Faktor-faktor yang Mempengaruhi Status Gizi Balita. Berita Kedokteran Masyarakat. 2009 September; 25 (03): p. $150-159$.

18. Shaikh, F.A., Wirat K., dan Sairudee V. Factors Affecting Nutritional Status of Five Years Old Children in Islamabad, Pakistan. Journal of Public Health and Development. 2007; Vol. 05 (03): p. 75-86.

19. Oddo, V.M., Jee H. R., Richard D. S., Kai S., Nasima A., Mayang S., Saskia D. P., Regina M., Martin B., dan Klaus K. Predictors of Maternal and Child Double Burden of Malnutrition in Rural Indonesia and Bangladesh. American Journal of Clinical Nutrition (Abstrak). 2012; Vol 95 (4) April 2012: p. 951 - 958. 